\title{
Condilomatosis gigante genital y perianal
}

\author{
Rodríguez Corchero J, Villodres Duarte A, Mármol Navarro S, Domínguez Usero D, \\ Osman García I, Rodríguez Pérez A.
}

Servicio de Urología. Hospital Universitario Virgen del Rocío. Sevilla.

Actas Urol Esp. 2007;31(2):177

$\mathrm{P}$ aciente varón de 41 años con antecedentes personales de adicción a drogas por vía parenteral (Ex.ADVP), SIDA (estadio 3), Hepatopatía viral (virus B, C y D positivos) y Tuberculosis en tratamiento, remitido a nuestro hospital por presentar condilomatosis gigante penoescrotal y perianal (Figs. 1 y 2).

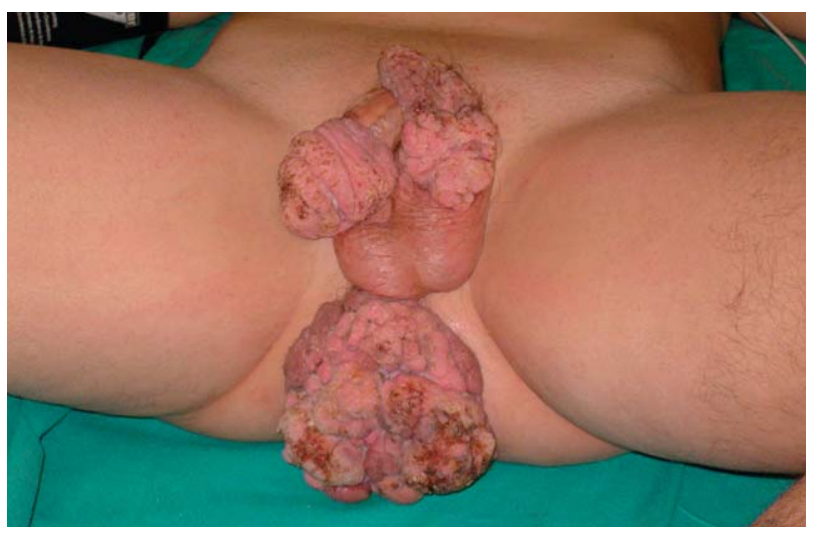

\section{FIGURA 1}

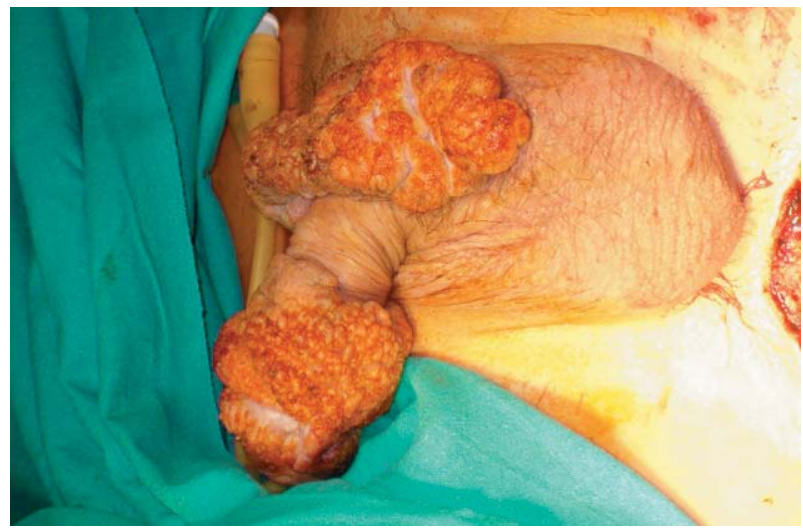

FIGURA 2
Ingresa para intervención quirúrgica reglada, interviniendo en la misma especialistas de Cirugía General (Coloproctología), Cirugía Plástica y Urología. Se realiza exéresis completa de los condilomas (Fig. 3), dejando una colostomía temporal de protección.

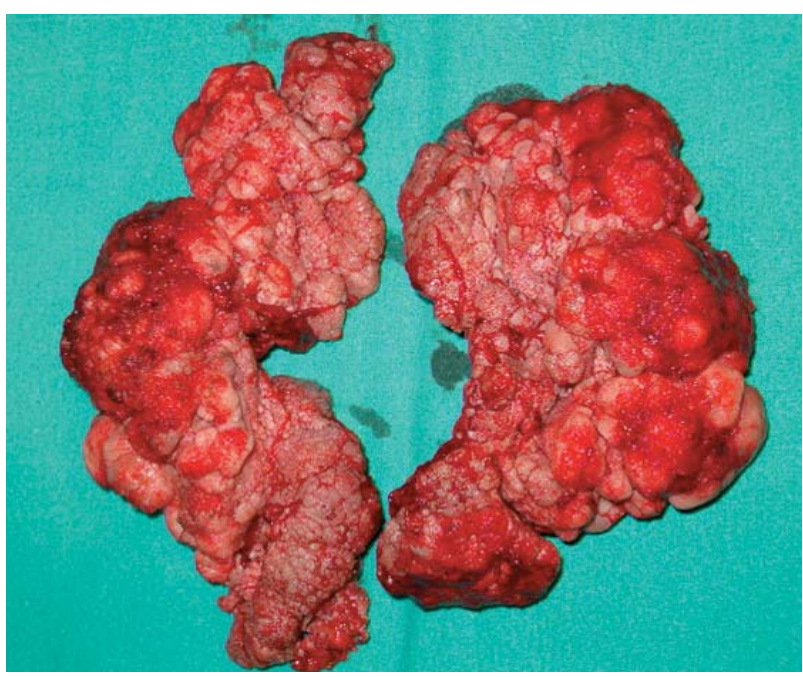

FIGURA 3

El análisis anatomopatológico de las piezas quirúrgicas confirma el diagnóstico de Condilomas acuminados.

Correspondencia autor: J. Rodríguez Corchero. Servicio de Urología. Hospital Infanta Elena Ctra. Huela-Sevilla, s/n 21007 Huelva. Tel.: 959015100

E-mail autor: jrcorchero@hotmail.com Información artículo: Imágenes en Urologia Trabajo recibido: enero 2006

Trabajo aceptado: marzo 2006 